J. Japan. Soc. Hort. Sci. 53(1) : 38-44. 1984.

\title{
Role of Pericarp in Reducing Spinach (Spinacia oleracea L.) Seed Germination at Supra-optimal Temperatures ${ }^{1}$
}

\author{
Norio Suganuma and Hajime Ohno \\ Laboratory of Horticultural Science, Faculty of Agriculture, \\ Nagoya University, Chikusa, Nagoya 464
}

\begin{abstract}
Summary
Germination of the spinach (Spinacia oleracea L. var. grabra cv. Nobel) seed was examined at supra-optimal temperatures. Almost all seeds germinated rapidly at $20^{\circ} \mathrm{C}$. However, germination decreased as temperature was raised and fell to about $10 \%$ at $35^{\circ} \mathrm{C}$. Removal of the pericarp as well as presoaking treatment markedly improved the germination, especially, at $35^{\circ} \mathrm{C}$. Germination of pericarp-removed seeds was inhibited by water soluble extracts from seeds and pericarp, but not by those from presoaked seeds. The inhibitory activity of the extracts was not affected much by the incubation temperatures before extraction. Sulfuric acid treatment conducted to modify the physical properties of the pericarp and hydrogen peroxide treatment conducted to elevate the oxygen tension promoted germination.

Thus, the poor germination at high temperatures may be caused mainly by the pericarp, which produces germination inhibitors or gives mechanical resistance and impermeability to gases. Even in the pericarp-removed seeds, germination was delayed at high temperatures, indicating that high temperature directly affected the embryo.
\end{abstract}

\section{Introduction}

It is well known that many seeds germinate within a relatively narrow range of temperature (13), and that they have optimum temperatures for germination, above which the germination decreases sharply depending on species and cultivars. Nowadays, vegetables are cultivated all the year round. Consequently, their seeds are not always sown at the optimum temperature. This results in poor germination and poor seedling emergence in practice.

The situation is especially true of spinach. Spinach is now cultivated extending from cool seasons in low lands to hot season in high lands. In high lands, the temperature of ten rises above $30^{\circ} \mathrm{C}$ in summer, so seed germination and seedling emergence in spinach, whose optimum temperature is

\footnotetext{
1 Received for publication June 21, 1983
}

This study was presented at the Autumn Meeting 1980 and the Spring Meeting 1982 of the Japanese Society for Horticultural Science. about $20^{\circ} \mathrm{C}(1,4,7,11)$, are often poor. This is a severe problem to be solved in high land spinach cultivation.

Germination of spinach seeds is poor even at optimum temperature. Heydecker and Orphanos(6) and Sugiyama(12) pointed out that the germination of spinach seeds was inhibited under wet condition by excess moisture in pericarp preventing oxygen supply. Other workers attributed the poor germination to growth inhibitors in the pericarp $(8,9)$. However, relatively few attempts have been made to elucidate the effect of supra-optimal temperatures on spinach seed germination. Recently, Atherton and Farooque (1) showed that hightemperature inhibition of germination in spinach seeds was mediated in part through the activity of inhibitors in the pericarp and suggested that a particularly sensitive phase to high temperature existed during the germination process. Here, we examined the role of pericarp in reducing the spinach seed germination at supra-optimal 
temperatures, with respect to germination inhibitors and physical properties of the pericarp.

\section{Materials and Methods}

Spinach seeds obtained from the Gifu-ken Highland Agricultural Experiment Station and Kosaka Seed Company, Ltd., Takayama, Gifu, were stored at $4^{\circ} \mathrm{C}$ in a desiccator for use in germination tests.

Seeds $(3.0 \sim 3.5 \mathrm{~mm}$ in diameter) were sown on 2 layers of filter paper (Toyo No. 2) moistened with $3.5 \mathrm{ml}$ of distilled water in 9-cm petri dishes(4). In cases of pericarpremoved, presoaked, and sulfuric acid-treated seeds, the volume of distilled water was decreased to $3.0 \mathrm{ml}$ considering the amount of water absorbed by pericarp. To maintain moisture, the petri dishes were kept in polyethylene boxes $(22 \times 26 \times 29 \mathrm{~cm})$ with some water at the bottom and moistened filter paper on the sides. The boxes were placed in temperature-controlled incubators (20, 27 and $\left.35^{\circ} \mathrm{C} \pm 1^{\circ} \mathrm{C}\right)$ for germination tests.

Pericarp-removed seeds were obtained by mildly grinding the seeds with mortar and pestle, and then by removing the opened pericarp with a pincette. In presoaking treatment, the seeds were soaked in running or still water for 1 or 24 hours and germinated at 20 and $35^{\circ} \mathrm{C}$. In sulfuric acid treatment, seeds were soaked in concentrated $\mathrm{H}_{2} \mathrm{SO}_{4}$ for $0,15,30,60$ or 120 minutes, rinsed with running water for an hour and then germinated at $35^{\circ} \mathrm{C}$. In hydrogen peroxide treatment, seeds were surfacesterilized with $1 \% \mathrm{NaClO}$, rinsed with sterilized distilled water and germinated at $35^{\circ} \mathrm{C}$ on the filter paper moistened with 3.0 $\mathrm{ml}$ of $0.5,1,2,3,6$ or $9 \% \mathrm{H}_{2} \mathrm{O}_{2}$ solution in petri dishes.

Before extraction, $9 \mathrm{~g}$ of intact seeds or $4.5 \mathrm{~g}$ of pericarp removed from seeds were incubated at 20 or $35^{\circ} \mathrm{C}$ for 1 day, then immersed in $300 \mathrm{ml}$ distilled water together with the filter paper, agitated with a shaker for an hour, and filtered. The filtrate was concentrated under reduced pressure and its final volume was adjusted to $3 \mathrm{ml}$ with distilled water. The concentrated extract was centrifuged at $2,500 \mathrm{rpm}$ for 10 minutes, and the supernatant liquid was tested for its inhibitory activity on spinach seed germination using pericarp-removed seeds prepared from intact seeds $2.5 \sim 3.0 \mathrm{~mm}$ in diameter. They were germinated at $20^{\circ} \mathrm{C}$ on the filter paper moistened with the extracts instead of distilled water.

Each treatment was triplicated with 100 seeds per replicate. Normal germination was judged by the appearance of the radicle tip. On the other hand, abnormal germination, in which cotyledons emerged prior to the radicle, was often observed in pericarpremoved seeds, especially, at high temperatures. In the present studies, normal and abnormal germination were not separated in counting the number of seeds germinated.

\section{Results}

At $20^{\circ} \mathrm{C}$, the seeds germinated most rapidly and the final germination was $87.3 \%$. Germination decreased with increased incubation temperatures and the final germination at 27 and $35^{\circ} \mathrm{C}$ was 71.3 and $11.0 \%$, respectively (Fig. 1).

Germination was improved at both 20 (Fig. 2-A) and $35^{\circ} \mathrm{C}$ (Fig. 2-B) by removing the pericarp, and it finally reached $89.0 \%$ even at $35^{\circ} \mathrm{C}$. Although germination was

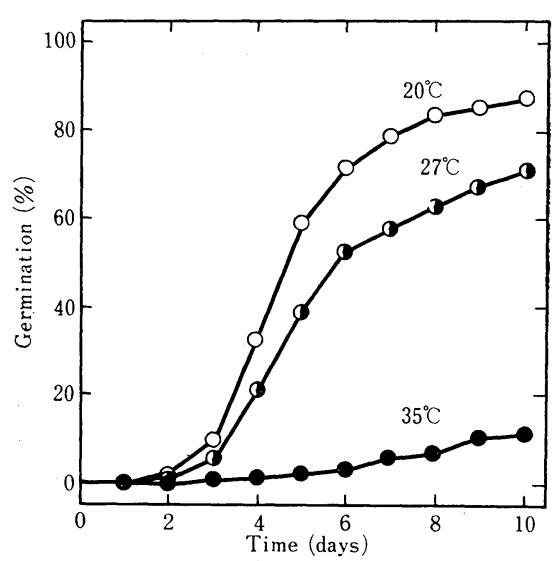

Fig.1. Effect of temperature on the germination of spinach seeds. Germination tests were conducted at $20^{\circ} \mathrm{C}(\mathrm{O}), 27^{\circ} \mathrm{C}(\bullet)$ and $35^{\circ} \mathrm{C}(\bullet)$ in 3 replications with 100 seeds each. Germination percentage was recorded at daily intervals for 10 days and averaged for 3 replications. 


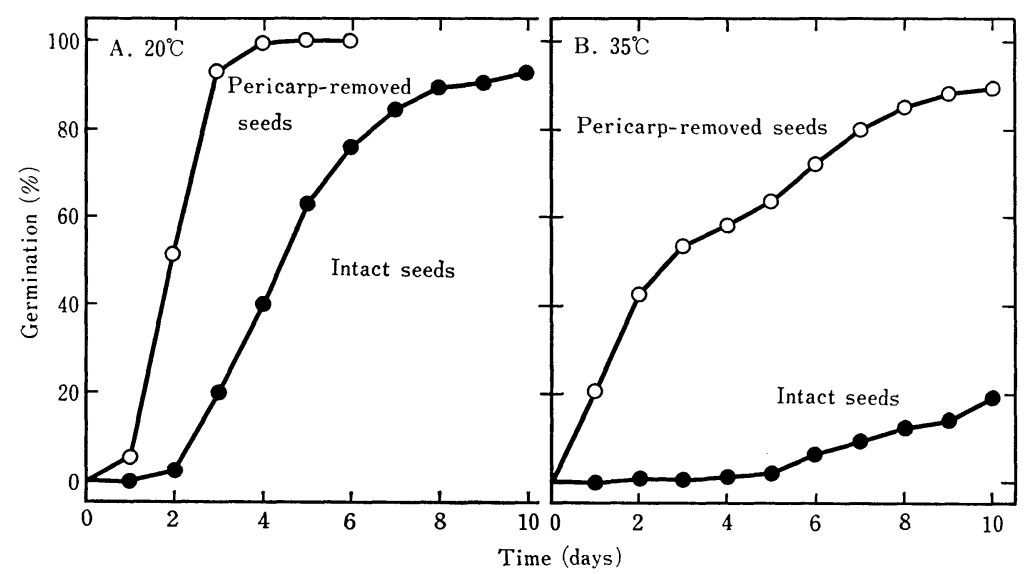

Fig.2. Effect of pericarp removal on spinach seed germination. Germination tests were conducted at $20^{\circ} \mathrm{C}(\mathrm{A})$ and $35^{\circ} \mathrm{C}(\mathrm{B})$ using intact seeds as control (•) and pericarp-removed seeds $(O)$ obtained by removing the pericarp mechanically.

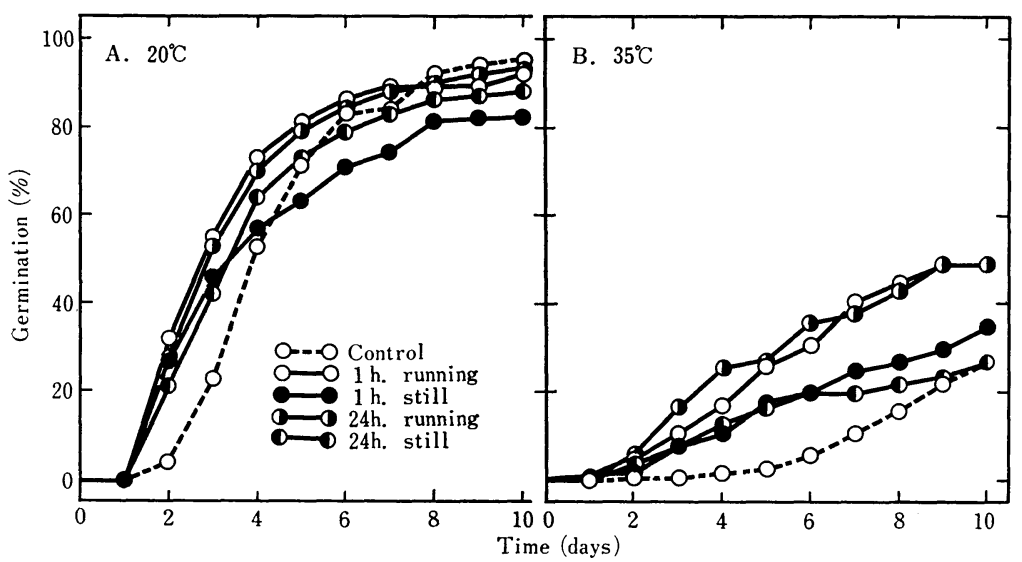

Fig.3. Germination of spinach seeds presoaked in water. Seeds were soaked in still or running water for 0,1 or 24 hours, and then germinated at $20^{\circ} \mathrm{C}$ or $35^{\circ} \mathrm{C}$ for a total period of 10 days including presoaking period.

Table 1. Effect of temperature and pericarp removal on germination behavior of spinach seeds.

\begin{tabular}{cccc}
\hline \multirow{2}{*}{$\begin{array}{c}\text { Temperature } \\
\left({ }^{\circ} \mathrm{C}\right)\end{array}$} & Pericarp & & \multicolumn{2}{c}{ Germination } \\
\cline { 3 - 4 } & & $\begin{array}{c}\text { Normal } \\
\text { (\% of total }\end{array}$ & $\begin{array}{c}\text { Abnormal } \\
\text { germination })\end{array}$ \\
\hline \multirow{2}{*}{20} & + & 99.5 & 0.5 \\
35 & + & 97.4 & 2.6 \\
& \pm & 88.1 & 11.9 \\
& - & 74.8 & 25.2 \\
\hline
\end{tabular}

$z$ A radicle emerged earlier than cotyledons.

y Cotyledons appeared first.

improved by pericarp removal, a high proportion of seeds produced abnormal seedlings (Table 1). Especially at $35^{\circ} \mathrm{C}, 25.2 \%$ of germination was abnormal. On the other hand, the percentage of abnormal germina- tion was very low $(2.6 \%)$ at $20^{\circ} \mathrm{C}$. Regardless of the pericarp intactness, abnormal germination was more common at $35^{\circ} \mathrm{C}$ than at $20^{\circ} \mathrm{C}$.

Germination was enhanced by presoaking treatment at both 20 and $35^{\circ} \mathrm{C}$. Running water was more effective than still water. While the effectiveness differed little between treatment durations of 1 and 24 hours (Fig. $3)$.

Germination of pericarp-removed seeds was inhibited by the water extracts obtained from seeds or pericarp after 1 day incubation at 20 or $35^{\circ} \mathrm{C}$. But there was little difference in inhibitory activities between incubation 


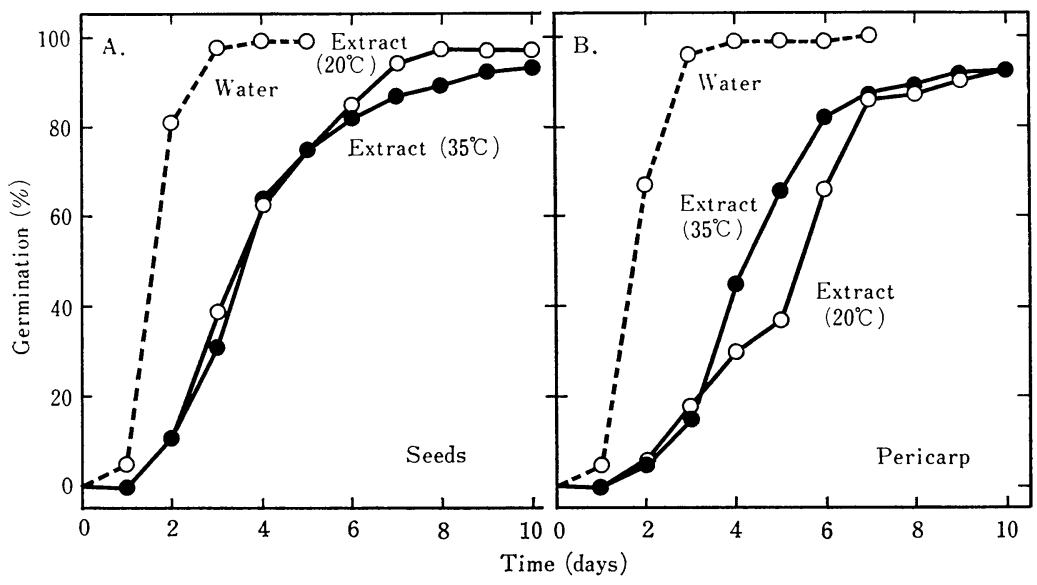

Fig.4. Inhibitory effect of water extracts of intact spinach seeds (A) and pericarp (B) on spinach seed germination. Water extracts were obtained after 1 day incubation at $20^{\circ} \mathrm{C}(-\circ-)$ or $35^{\circ} \mathrm{C}(-\bullet-)$. Germination tests were carried out at $20^{\circ} \mathrm{C}$ with pericarp-removed spinach seeds, which were sown on the filter paper moistened with water extracts instead of distilled water.

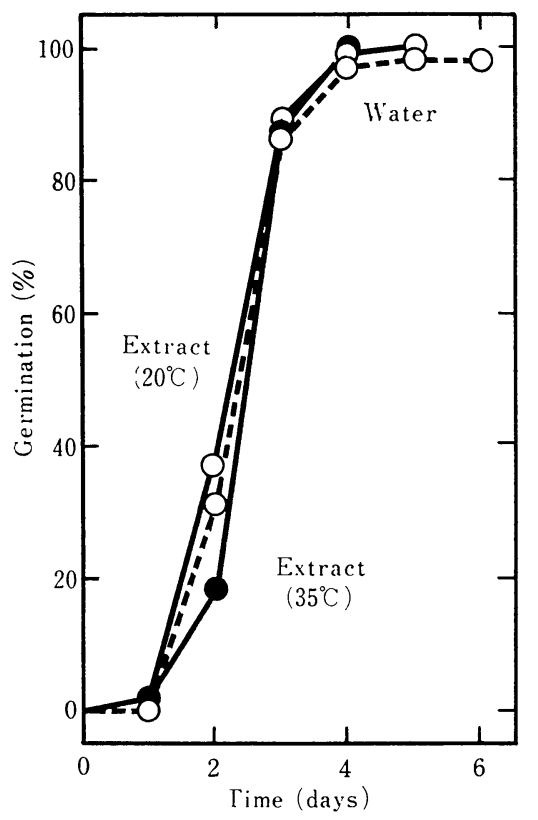

Fig.5. Change in inhibitory activity of water extracts of presoaked seeds. Seeds were soaked in running water for an hour and then incubated at $20^{\circ} \mathrm{C}(-\circ-)$ or $35^{\circ} \mathrm{C}(-\bullet-)$. After 1 day incubation, water extracts of the seeds were obtained and tested for their inhibitory activity at $20^{\circ} \mathrm{C}$ by germination tests using pericarpremoved spinach seeds.

temperatures before extraction (Fig. 4). However, no inhibitory activity was detected in water extracts obtained from the seeds

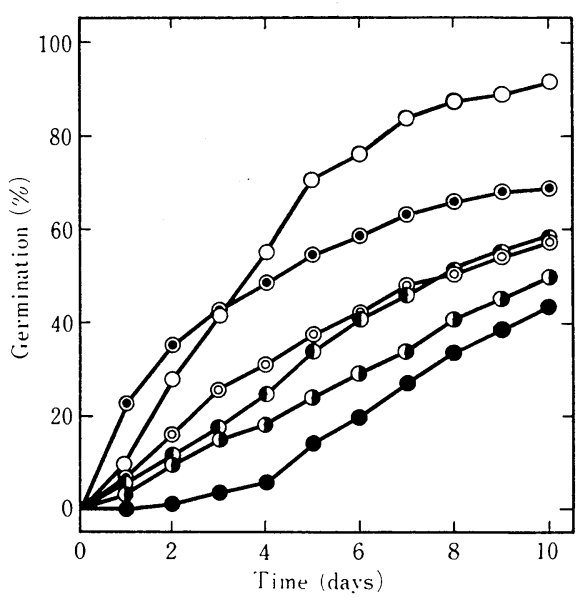

Fig.6. Effect of sulfuric acid treatment on spinach seed germination at $35^{\circ} \mathrm{C}$. Seeds were soaked in concentrated $\mathrm{H}_{2} \mathrm{SO}_{4}$ for $0(\bullet), 15(\bullet), 30$ (D), $60(0)$ or $120(0)$ minutes, rinsed in running water for an hour, and then germinated at $35^{\circ} \mathrm{C}$. As control, pericarp-removed seeds $(0)$ were also germinated.

presoaked and incubated at 20 or $35^{\circ} \mathrm{C}$ (Fig. 5).

Sulfuric acid treatment conducted to modify the physical properties of the pericarp also promoted germination at $35^{\circ} \mathrm{C}$ (Fig. 6). Although germination (increased with the duration of treatment, 60 and 120 minutes treatments apparently damaged the seeds. Similarly, hydrogen peroxide treatment con- 


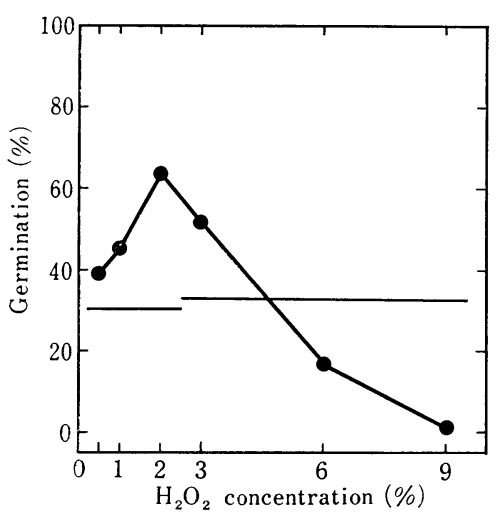

Fig.7. Effect of hydrogen peroxide treatment on seed germination at $35^{\circ} \mathrm{C}$. Surface-sterilized seeds were rinsed with sterilized distilled water, sown on the filter paper moistened with $\mathrm{H}_{2} \mathrm{O}_{2}$ solution or distilled water in petri dishes, and then germinated at $35^{\circ} \mathrm{C}$. After 10 days, germination percentage was recorded. Horizontal lines indicate water control. This figure is composed of 2 separate experiments.

ducted to elevate oxygen tension was effective in promoting germination at $35^{\circ} \mathrm{C}$ (Fig. 7). Two percent hydrogen peroxide, which was most effective, improved the germination of intact seeds rather than that of pericarpremoved seeds (Fig. 8).

\section{Discussion}

As shown by earlier workers $(1,4,7,11)$, germination of spinach seeds was inhibited at high temperatures (Fig. 1). At the same time, germination was promoted by pericarp removal at both 20 and $35^{\circ} \mathrm{C}$ (Fig. 2). These results seem to indicate that the poor germination at high temperatures was caused by the pericarp. However, even in the pericarp-removed seeds, germination was delayed at $35^{\circ} \mathrm{C}$ (Fig. 2). This suggests that high temperature also affects the embryo per se, resulting in poor germination. According to earlier reports, germination in spinach seeds was promoted by presoaking treatment $(1,4,11)$. This was confirmed in the present experiment (Fig. 3). The germination of pericarp-removed seeds was inhibited by water extracts from seeds and pericarp, but not inhibited by those from presoaked seeds (Figs. 4 and 5). Therefore, it is inferred that the water soluble germination inhibitor present in the pericarp can be readily removed by presoaking treatment. Ishikawa(8) and Makino and Miyamoto(9) reported picric and oxalic acids as inhibitors present in the pericarp, respectively. However, the inhibitor detected in our experiment was not identified.

Berrie(2) suggested that lack of germination in lettuce seeds at high temperatures was due to the accumulation of an inhibitor produced by a system with a $\mathrm{Q}_{10}$ effectively greater than all the processes that contributer to its loss. Berrie's suggestion was not confirmed in our experiments with

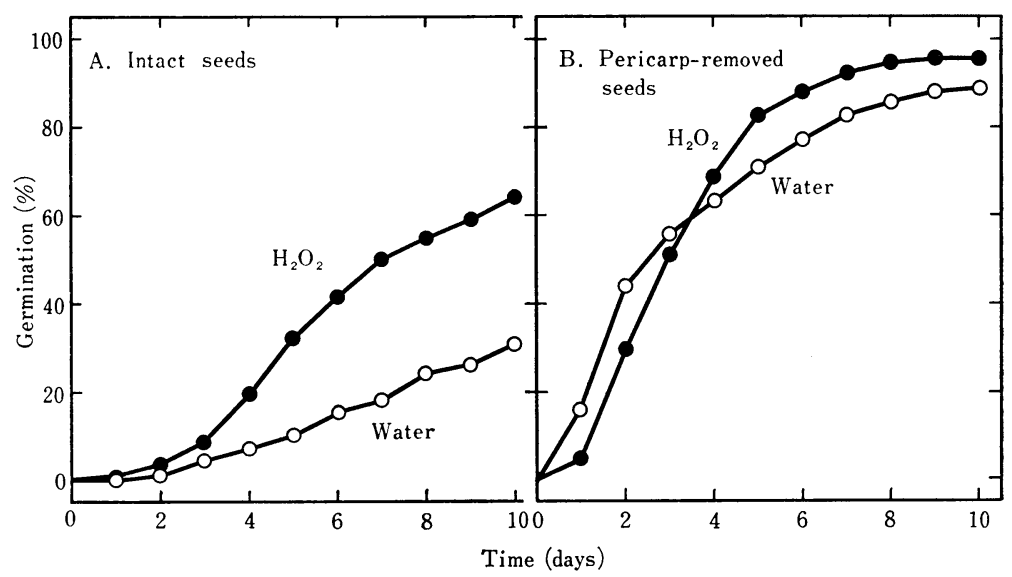

Fig.8. Effect of $2 \% \mathrm{H}_{2} \mathrm{C}_{2}$ solution on the germination of intact seeds (A) and pericarp-removed seeds (B) at $35^{\circ} \mathrm{C}$. Seeds were germinated as shown in the legend of Fig.7. 
spinach seeds. That is, there was little difference in inhibitory activities of our water extracts between incubation temperatures before extraction (Figs. 4 and 5). This indicates that the incubation temperatures before extraction affected neither the content nor the activity of the water soluble inhibitor present in the pericarp. If so, there would rise a possibility that the inhibitory activity, which was tested at $20^{\circ} \mathrm{C}$, could be higher at high germination temperatures. Although this possibility was not studied in the present experiment, the inhibitory effect of the pericarp at high temperatures may not be attributed to the water soluble inhibitor only, for the inhibitory effect of the pericarp was not completely removed by presoaking treatment (Figs. 2 and 3). Water insoluble inhibitor, which was not studied in the present experiment, may also cause poor germination at high temperatures.

It is possible that another inhibitory function probably produced by the physical properties of the pericarp, such as mechanical resistance to embryo growth and impermeability to gases might exist(10). This seems to be confirmed by the results of the sulfuric acid and hydrogen peroxide treatments (Figs. 6, 7 and 8). Sulfuric acid treatment for 30 minutes can be adopted in practical cultivation. Treatments for 60 and 120 minutes would be too long and undesirable for the embryo.

Haber and Luippold (5) indicated that cellular expansion within the embryo of lettuce seed was prerequisite to germination. The overall expansion of the embryo was inhibited at supra-optimal temperatures by the presence of the endosperm(3). However, it is not clear how the endosperm, or the pericarp in the case of spinach, inhibits the germination at high temperatures. There are 2 possibilities. One is that the pericarp may change in its gaseous permeability, which limits the oxygen uptake by the embryo at high temperatures. The other is that even if the pericarp does not change in its physical properties, the embryo is so affected by high temperatures as to increase the relative mechanical resistance of the pericarp and reduce the germination. Atherton and Farooque (1) suggested a possibility that at high temperatures, inhibitors in the pericarp might prevent spinach seed germination by increasing the embryo's requirement for oxygen beyond the level available. Their hypothesis can not be necessarily accepted, because hydrogen peroxide promoted germination even in the seeds from which germination inhibitor was removed through a surface-sterilization step. or pericarp removal (Fig. 8).

As discussed above, the poor germination of spinach seeds at supra-optimal temperatures seems to be mostly due to the germination inhibitor and physical properties of the pericarp, but in part due to the direct effect of high temperatures on the embryo.

\section{Acknowledgment}

We wish to thank Mr. Y. Haga, Gifu-ken Highland Agricultural Experiment Station, Furukawa, Yoshiki, Gifu, for his useful advice and offer of spinach seeds. We also thank professor Y. Yamamoto for reading this manuscript and his helpful discussions and Dr. T. Tezuka for his helpful advice.

\section{Literature Cited}

1. Atherton, J. G. and A. M. FArooque. 1983. High temperature and germination in spinnach. I. The role of the pericarp. Scientia Hortic. $19: 25-32$.

2. BERrie, A. M. M. 1966. The effect of temperature and light on the germination of lettuce seeds. Physiol. Plant. 19:429-436.

3. FOARD, D. E. and A. H. HABER. 1966. Mitoses in thermodormant lettuce seeds with reference to histological location, localized expansion and seed storage. Planta $71: 160-170$.

4. Futatsudera, T., Y. Haga, N. Koike and A. WADA. 1978. Experiments to develop a summer-harvesting system in spinach cultivation. IX. Germination properties of the seeds. Annu. Rep. Gifu-ken Highland Agr. Exp. Sta. 15-16. (In Japanese)

5. HABER, A. H. and H. J. LUIPPOLD. 1960. Separation of mechanisms initiating cell division and cell expansion in lettuce seed germination. Plant Physiol. $35: 168-173$.

6. HEYDECKER, W. and P. I. ORPHANOS. 1968. The effect of excess moisture on the germination of Spinacia oleracea L. Planta 83: 
$237-247$.

7. INAGAWA, T. and I. MiYASE. 1943. Minimum, optimum and maximum temperatures for germination of vegetable seeds. Agriculture and Horticulture $18: 763$. (In Japanese)

8. ISHIKAWA, S. 1951. On the growth inhibitor present in the spinach fruit. Bot. Mag. 64 : 120-125. (In Japanese with English summary)

9. MAKINO, I. and T. MiYamoto. 1954. On the growth inhibiting substance in the germinating spinach seeds. Japan J. Breed. 4 : 158160. (In Japanese with English summary)
10. MAYer, A. M. and Y.Shain. 1974. Control of seed germination. Ann. Rev. Plant Physiol. $25: 167-193$.

11. SUGIYAMA, N. 1944. Reason and countermeasure for poor germination of spinach seed. Agriculture and Horticulture $19: 297-298$. (In Japanese)

12. SugiYAma, N. 1944. Germination method of spinach seed. Agriculture and Horticulture $19: 407-408$. (In Japanese)

13. WENT, F. W. 1953. The effect of temperature on plant growth. Ann. Rev. Plant Physiol. $4: 347-362$.

\title{
高温条件下におけるホウレンソウ種子の発芽に及ぼす果皮の抑制作用
}

\author{
菅沼 教生・大 野 始 \\ 名古屋大学農学部 464 名古屋市千種区
}

\begin{abstract}
摘 要
ホウレンソウ種子の発芽に及ぼす高温の影響につい て，西洋系品種ノーベルを用いて検討した．発芽は 20 ${ }^{\circ} \mathrm{C} て ゙$ 最も良く，温度が高くなるにつれて抑制され， $35^{\circ} \mathrm{C}$ における発芽率は10\%程度であった。高温に佂ける発芽 不良は，果皮の除去によって著しく改善された。また， 水への浸漬処理によっても発芽は促進された．果皮を除 去した種子の発芽は, 種子及び果皮の水抽出液により抑 制されたが，浸漬処理をした種子の水抽出液では抑制さ

ど見られなかった。これらのことから，果皮中に発芽抑 制物質が存在することが示されたが，硫酸処理，過酸化 水素処理によっても発芽率が向上したことから，高温に 打㤝果皮の発芽抑制作用を，果皮中の発芽抑制物質の みに帰することはできず，果皮の機械的強度やガスの透 過性などの物理性も関与していることが示唆された。 た，果皮を除去した種子でも，高温における発芽速度が 遅く, 肧への高温の直接的影響も認められた.
\end{abstract} れず，抽出前の置床温度による抑制効果の違いもほとん 